\title{
Modification of Tillage Implements for Alley Cropping System
}

\author{
John Morris Togo Kaji ${ }^{1} \quad$ Adam H.Yagoob $^{2} \quad$ Sheikh El Din E. A ${ }^{3} \quad$ Wang Decheng ${ }^{4}$ \\ 1.Department of Agricultural Engineering; China Agricultural University, Beijing100083, China \\ 2.College of Humanities and Development Studies, China Agricultural University, Beijing, China \\ 3.Agricultural Research Corporations, Wad Medani, Sudan \\ 4.Department of Agricultural Engineering; China Agricultural University, Beijing, China
}

\begin{abstract}
Sustainable alley agriculture in the agro-forestry cropping system becomes a great challenge due to the lack of suitable land preparation, using the conventional tillage system "The three-bottom disc plough". This research is an attempt to modify the conventional tillage implement for better use in agroforestry system. The modified Tillage System, in comparison with 3-bottom disc plough, showed significantly lower tractor actual speed, higher wheel slippage, effective field capacity and higher draught requirements. For the secondary operations, no significant differences were detected between modified tandem and the offset disc harrow, except for the tractor actual speed, where the offset disc harrow resulted in significant higher speed. Moreover, the modified tillage implements shows lower un-ploughed length area within the alley, and two meters increase in the preparation of the available cultivated area compared to the conventional system, and significantly lower bulk density at crop emergence stage only. The modified implements resulted in higher initial and final infiltration rate after seedbed preparation and at harvest in comparison with the conventional system. With regards to crop yield, the modified tillage system resulted in significant higher grain yield in the first and second seasons, in comparison with the use of the conventional tillage system.
\end{abstract}

Keywords: draught requirements, tillage implements, alley cropping, soil cold size, bulk density, superficial lateral root, infiltration rate

\section{Introduction}

The shortest width of cut of the three-bottom disc plough is not applicable for the tractor to pass underneath of the trees canopies; moreover, it is not possible to plough a considerable area to the north and south direction of the tree rows, resulted in un-ploughed areas along the alley edges, so the three bottom disc plough is not effective in pruning lateral roots of trees, hence reducing crop yield. To overcome the problems of alley land preparation, a suitable tillage tool should be modified to achieve the followings;

a) Maximum utilization of the available land within the alley cropping system.

b) Destruction of the lateral roots of the trees that compete with crops for water and nutrients

c) Better crop growth performance and higher yield.

d) The modified tillage tools should match the available medium size tractor drawbar power.

The experimental work of this research paper was carried out at the Agro-forestry experimental field within an Alley Cropping System in the Gezira Research Station in Wad Medani; Sudan. The experiment was laid-out in 8meter alley spacing where Acacia ampliceps trees were grown, and considered one of the agro-forestry trees that have a heavy canopy and competitive lateral roots in the upper layers of the alley soil. The evaluation covered the tractor and implement performance, maximum utilization of the available alley land, superficial root pruned length, soil clod size distribution, infiltration rate, soil bulk density and its corresponding soil moisture content, in addition to yield and yield components. The experiment was arranged in a randomized complete block design with three replications. The subplot size was $8 \times 10 \mathrm{~m} 2$.

\section{Agro-forestry cropping system}

Traditional agroforestry systems already have a long history and still play a significant role in the world today, especially in tropical and subtropical areas. In this era of globalization and food in security, more and more governments and non-governmental organizations are paying attention to traditional agroforestry systems because of their economic, ecological and multiple ecosystem services and precious socio-culture values at a regional and global level. Although traditional agroforestry systems are confronted with many threats and challenges, such as population growth, migration, market impact, climate change and so on, as long as governments and nongovernmental organizations, local communities and smallholders can cooperate with each other, traditional agroforestry systems will be effectively protected and will remain in the future a sustainable global land use practice.

Agro-forestry systems involve growing woody herbaceous perennial species together with food crops and livestock on the same piece of land. Agro-forestry systems have been described extensively in several reports (Kang et al., 1990). Alley cropping was conducted by some scientists in the semi-desert region of northern Sudan during $1998-2000$ with the aim of investigating the potential of alley cropping system for the exploitation of 
residual water in the surface horizons and beyond the root depth of associated crops (Shapo and Adam, 2006). There is strong evidence that alley cropping system can lead to vigorous growth and yield advantages compared with sole cropping, due to its ability to modify crop microclimate and improve water use efficiency. Shapo and Adam (2008) reported that due to improvement of alley cropping microclimate in northern Sudan, the water use efficiency increased during winter, summer and autumn by $27 \%, 60 \%$, and $23 \%$, respectively. Consequently, wheat, faba bean and common bean yields were increased by $69 \%, 16 \%$ and $10 \%$, respectively, while carrot yield, during summer season was increased by 300\%. Several studies have shown the beneficial effects of trees on associated crops in agroforestry systems. Yu et al. (1997) reported that the modification of microclimate by Paulownia trees favoured the growth of tea (Camellia sinesis) plants and improved the quality of tea leaves. This, in turn, increased economic returns per unit land area. In the semi-desert region of northern Sudan, astenophylla tree, with its deep roots and open canopy, used the least water $(185 \mathrm{~m} 3 /$ feddan $)$, while ampliceps used the highest water (205m3/feddan), probably through its lateral roots (Shapo and Adam, 2003). Ampliceps with its bally and dense canopy effected lower solar irradiance. Its competitive root system extended laterally towards the centre of the alley giving lower saving in irrigation water and accordingly the lowest seed yield. Agroforestry offers substantial scope for complementarity water use, since the root system of woody trees is much deeper than those of the agricultural crops. While crops intensively utilize profile water from shallow depths, trees have potential to extract water from deeper layers compared to mono-cropping systems (Narain, et al., 1998). Suitable preparation of the alley land in the agro-forestry cropping system becomes a great challenge, because the 3-botten disc plough is the only implement that is used in primary tillage operations (Yu et al., 1997).

\section{The Modification Process}

\subsection{Chisel plough and Tandem disc harrow}

The modification was done by adding extra lengths of 1 meter long to the two outer sides of the main frame. The modified cutting width increased from 2.27 to 4.40 meter. Eleven rigid shanks, each of 0.7 meter in height were fixed alternatively on the two bars at a spacing of 0.40 meter apart. The two extended parts were made articulated to be raised upwards for transportation. The steel used for the extension parts was 3 inches angle which was similar to the one that the main frame was made of. The parts were welded and fixed to the main frame on three join points. The joint points were fitted with bolts. Eleven shanks were alternatively arranged on the modified frame of 4.4 meter width of cut, five shanks on the front row and 6 shanks on the rear row

The width of the original tandem disc harrow was extended by 0.24 meter on both outer sides of the main frame, which was 1.31 meter in width, to reach 1.79 meter in width. This modified frame gave flexibility to the gang shanks to be moved to the outer sides along the frame length. Therefore, each pair of gangs were arranged to cover 1.6 meter in width, with un-harrowed length of 1.40 meter in between, that would be covered in the second pass with overlapping of $10 \mathrm{~cm}$ to each side. This sort of modification was done to keep the implement without changes in draught and to match the medium size tractor power. An extension frame of 4 x 4 inches and 0.24 meter long was welded to 3 inches angle on both outer sides the main frame.

In addition to the modified chisel plough and modified tandem disc harrow, two other implements were used for the purpose of evaluation. A Disc plough, "Balaam Brazilian made", fully mounted on three point linkage, each with three discs of $66 \mathrm{~cm}$ in diameter and 0.9 meter cutting width was used for primary tillage. An Offset disc harrow "Turkish made" fully mounted on the tractor three point linkages, with eight notched discs in the front gang and eight plain discs in the rear gang was used for secondary tillage. Each disc was $52 \mathrm{~cm}$ in diameter, and the implement has a 2.4 meter width of cut.

\section{Testing Process}

\subsection{Power requirement and Measuring equipment}

Two types of tractors were used in the study. A Massey Ferguson, model MF 290, two wheel drive tractor, with about 70 P.T.O horse power (hp), was used as the main test tractor to operate all tillage implements. On other hand, a John Deere, model 7800, four wheel drive tractor with about 140 P.T.O hp was used as an auxiliary tractor to pull the main test tractor with attached implements for draught measurement.

The dynamometer used for draught measurement was a hydraulic pull type, PIAB dynamometer, Swedish made. It is provided with a screen through which the readings appear. The readings were expressed in KN with grading of one KN. For use, it was fixed between the rear axle of the front auxiliary tractor (pulling tractor) and the front axle of the rear test tractor (pulled tractor). A Double ring infiltrometer was used for determination of water infiltration rate (Landon, 1984). It was composed of two cylinders; the outer cylinder was $50 \mathrm{~cm}$ in diameter, while the inner cylinder was $30 \mathrm{~cm}$ in diameter. Both cylinders were made of sheet steel. In addition other accessories, such as a heavy weight plate, a plastic sheet, a stopwatch, and ruler were used. The sieves for determining soil clod size distribution were made from steel strips. The sieve frame was $30 \mathrm{x} 30 \mathrm{~cm}$ with different opening sizes $(25,16,9,4$, and $1 \mathrm{~cm} 2)$. In addition a driven frame with the same dimensions $(30 \times 30 \mathrm{~cm})$ was used. 


\subsection{Experimental field site}

The experimental work was carried out at the Agro-forestry experimental field within an Alley cropping system in the Gezira Research Station in Wad Medani. The experiment was laid-out in 8-meter alley spacing where Acacia ampliceps trees were grown. Acacia ampliceps is considered one of the agro-forestry trees that have a heavy canopy and competitive lateral roots in the upper layers of the alley soil.

Two tillage treatments were tested under the alley cropping system, which were:

- $\quad$ Modified system (Modified chisel plough + Modified tandem disc harrow).

- $\quad$ Traditional system (3- bottom disc plough + Offset disc harrow).

Wheat (Varity Debiera), as a test crop, was sown at the seed rate of $143 \mathrm{~kg} / \mathrm{ha}$ as recommended. A bed planting seed drill with three rows at $80 \mathrm{~cm}$ apart was used for crop sowing. The fertilizer (urea) was applied at the rate of $190 \mathrm{~kg} / \mathrm{ha}$. The crop was sown on 23rd of November 2007 in the first season and 25th of December 2009 in the second season. The experiment was arranged in a randomized complete block design with three replications. The subplot size was $8 \times 10 \mathrm{~m}$.

\section{Methodology and data collection}

\subsection{Measurement of the implement draught}

The two tractors with different P.T.O hp were used, in a separate test, to determine the draught requirement for the modified chisel plough and disc plough at $20 \mathrm{~cm}$ working depth and the modified tandem disc harrow and offset disc harrow at $10 \mathrm{~cm}$ working depth in the open field. The tractor with the attached implement, the auxiliary tractor and the dynamometer were set as described by Bukhari et al. (1992). The first measurement was taken while the auxiliary tractor was pulling the test tractor when not on gear and with unloaded implement. The second measurement was taken while the auxiliary tractor was pulling the test tractor when not on gear but with loaded implement. The two measurements were repeated three times for each implement with the specified working depth using the position control system of the test tractor. The draught readings were recorded in $\mathrm{KN}$ for a 30 meter distance. Traveling time was measured with a stop watch. Then, the draught for each implement was calculated as follows (Khalid, 2000):

$$
S D=D_{L}-D_{0}
$$

Where: $\mathrm{SD}=$ Soil draught $(\mathrm{KN}) . \quad \mathrm{D}_{\mathrm{L}}=$ Pull with loaded implement $(\mathrm{KN}) . \mathrm{D}_{\mathrm{o}}=$ Pull with unloaded implement $(\mathrm{KN})$.

\subsection{Measurement of travel reduction, the drawbar power and Tractor actual speed}

To determine the wheel slip \%, the rear wheel of the test tractor was marked at a position tangent to the ground surface with white chalk. Then the tractor was allowed to move forward for ten revolutions of the rear wheel without load and the distance (VO) was measured using a measuring tape. Then the tractor was also allowed to move another ten revolutions with loaded implement and the distance (VL) was measured. The travel reduction was calculated using the following formula (Barger et al., 1963).

$$
W S=\left(1-\frac{V_{L}}{V_{O}}\right) 100 \%
$$

Where: WS $=$ Wheel slip $(\%) . V_{L}=$ the travelled distance with load $(\mathrm{m}) . \mathrm{V}_{\mathrm{O}}=$ the travelled distance without load (m).

The actual drawbar power is the power used for pulling or moving the implement at a uniform speed. The drawbar power exerted by the tractor on the implement was calculated using Equation (1) (El-Awad and Crossley 2003).

$$
P_{f}=F_{x} V
$$

Where: $\mathrm{P}_{\mathrm{f}}=$ Available drawbar power $(\mathrm{kW}) . \mathrm{F}_{\mathrm{x}}=$ The available drawbar pull $(\mathrm{KN}) . \mathrm{V}=$ Actual forward speed $(\mathrm{m} / \mathrm{s})$.

The tractor actual speed was determined in $\mathrm{m} / \mathrm{s}$ by recording the time taken per trip for each implement separately to cover the subplot and using the following equation.

$$
A S=\frac{D(m)}{T(s)}
$$

Where: $\mathrm{AS}=$ Actual speed $(\mathrm{m} / \mathrm{s}) . \mathrm{D}=$ Distance $(\mathrm{m}) . \mathrm{T}=$ Time taken $(\mathrm{s})$.

\section{3 Theoretical and Effective field capacity}

The theoretical field capacity of each tested implements was calculated.

$$
C_{t}=\frac{S W}{10}
$$

Where: $\mathrm{C}_{\mathrm{t}}=$ Theoretical field capacity (ha hr-1). $\mathrm{S}=$ Speed of operation $(\mathrm{km} \mathrm{hr}-1) .=$ Width of implement $(\mathrm{m})$. $10=$ Factor $($ constant $)$, which is $=(10000 \mathrm{~m} 2 / \mathrm{ha} / 1000 \mathrm{~m} / \mathrm{km})$

The effective field capacity (work rate) was determined, in hectares per hour within the subplot, for each implement using Equation (4) 


$$
C_{e}=\left(\frac{S W}{10}\right) E_{f}
$$

Where: $\mathrm{C}_{\mathrm{e}}=$ Effective field capacity $\left(\mathrm{ha} \mathrm{hr} \mathrm{hr}^{-1}\right) \mathrm{S}=$ Speed of operation in $\left(\mathrm{km} \mathrm{hr}^{-1}\right) . \mathrm{W}=$ Width of implement $(\mathrm{m})$. $E_{\mathrm{f}}=$ Field efficiency, $10=$ Factor $($ constant $)$, which is $=\left(10000 \mathrm{~m}^{2} / \mathrm{ha} / 1000 \mathrm{~m} / \mathrm{km}\right)$

After the ploughing operation only, six trees were randomly selected in the south and the north directions of the tree rows for each tillage treatment and a root area of $1.2 \times 1.0 \mathrm{~m}$ was measured to determine the pruned roots length after manual searching in the ploughed upper layer of the soil $(20 \mathrm{~cm} \mathrm{depth})$.

\subsection{Soil clod size distribution, bulk density and corresponding moisture content}

After tillage treatments application, soil samples for clods size distribution were taken from soil layers of $15 \mathrm{~cm}$ depth by driving the frame of $30 \times 30 \times 10 \mathrm{~cm}$ into the soil smoothly using a hammer. Then, the soil volume within the frame was sieved by the different size sieves. The soil clods that remained on each sieve were weighed separately, and taken as a percentage of the total weight of the soil sample.

The soil bulk density and its corresponding moisture content were determined at three different depths, which were $0-10,10-20$ and $20-30 \mathrm{~cm}$. The measurements were taken at crop emergence, heading and maturity stages. The bulk density was determined using the core method (Blake and Hartge, 1986). The core sampler was driven vertically and very carefully by means of a hammer to the required depth, and then carefully removed by a shovel, and the soil on the core wall was removed using a flat edged knife. Three soil samples per plot were taken. The soil samples were weighed and oven-dried at 1050C for 24 hours following the procedure of Blake (1965). For the soil bulk density and soil moisture content determination, the following equations (Blake and Hartge, 1986) were used respectively.

$$
S B D=\frac{W_{d}(\mathrm{Mg})}{V\left(\mathrm{~cm}^{3}\right)}
$$

Where: $\mathrm{SBD}=$ Soil bulk density. $\mathrm{W}_{\mathrm{d}}=$ Dry weight of soil sample $(\mathrm{Mg}) . \mathrm{V}=$ Volume of sample in $\left(\mathrm{cm}^{3}\right)$.

$$
S M C=\left(\frac{W_{w}-W_{d}}{W_{d}}\right) 100 \%
$$

Where: $\quad$ SMC $=$ Soil moisture content $(\%) . \mathrm{W}_{\mathrm{w}}=$ Weight of wet soil sample $(\mathrm{g}) . \mathrm{W}_{\mathrm{d}}=$ Weight of oven-dry soil sample (g).

\subsection{Un-ploughed area and Infiltration rate}

The alley cropping system was divided into south, central and north zone. The south and the north zones surrounded the trees' rows. The south zone has irrigation channels, which were about 60 to $70 \mathrm{~cm}$ in width. The north zone is the most un-ploughed area within the alley and very congested by superficial lateral roots. The unploughed area was determined after ploughing operation. The distance left between the ploughed land and the tree rows was measured for both sides of the alley along the edges, which are known as north and south zones. Then the means of the readings were determined. The measurements were taken for each plot at both sides. The unploughed area was expressed as a percentage from the ploughed area.

Each of the two primary tillage treatments was randomly assigned for the installation of the infilterometer. Measurement of the infiltration rate was taken immediately after treatments the primary tillage operation execution and after crop harvest. The two cylinders were hammered into the soil to about $20 \mathrm{~cm}$ depth. The plastic sheet was placed in the inner cylinder. The two cylinders were filled with water. At zero time the plastic sheet was removed and the water drop was measured by the ruler and the elapsed time was recorded by the stopwatch. The infiltration rate was recorded after 5, 10, 15, 30, 60, 90, 120, 180, 240 and 300 minutes (Landon, 1984; FAO, 1986)

For crop emergence/m2 ten random readings were taken per subplot after the second irrigation using a $0.25 \times 0.40 \mathrm{~m}$ metal frame, while plant population was determined at maturity by the same procedure. For the plant height, harvested grain yield per subplot of $(5 \times 3.2 \mathrm{~m})$. The SAS system was used for the analysis of variance.

\subsection{Efficiency}

In this study the efficiency was taken as $70 \%$ for primary tillage operations and $74 \%$ for secondary tillage operations (Kepner et al., 1976).

\section{Results and Discussion}

\subsection{Tractor actual speed and implement performance}

Results of the tractor actual speeds with the use of primary tillage implements showed that the 3-bottom disc plough resulted in significantly $(\mathrm{P}=0.05)$ higher tractor actual speed in comparison with the use of the modified chisel plough. For the secondary tillage implements, the offset disc harrow resulted in significantly $(\mathrm{P}=0.05)$ higher tractor actual speed compared to the modified tandem disc harrow. The reduction in the speed for both modified tillage Implements were due to their increased width of cut compared to the conventional ones (Table, 1).Tractor wheels slippage results in a reduction of forward speeds, which in turn results in power loss, high fuel consumption, in addition to tear and wear of tires which affect the tractor pulling efficiency. The obtained results 
indicated that since the modified chisel plough width of cut was five folds greater than 3-bottom disc plough, it resulted in significantly $(\mathrm{P}=0.05)$ higher travel reduction compared to the 3-bottom disc plough for the same ploughing depth $(20 \mathrm{~cm})$. Furthermore, although the modified tandem disc harrow was greater in width of cut (3.2 $\mathrm{m})$ compared to the offset disc harrow $(2.4 \mathrm{~m})$, there was no significant difference between the secondary tillage implements; they were almost similar in travel reduction, for the same depth of harrowing $(10 \mathrm{~cm})$.

Table 1: machine performance

\begin{tabular}{lcccc}
\hline \multirow{2}{*}{ Treatment } & \multicolumn{5}{c}{ Measured Parameter } \\
\cline { 2 - 5 } & Ploughing depth $(\mathrm{cm})$ & Width of cut $(\mathrm{cm})$ & Actual speed $(\mathrm{m} / \mathrm{s})$ & Wheel slope $(\%)$ \\
\hline Primary tillage implement & & & 1.41 & 15.3 \\
\hline Modified chisel plough & 20 & 4.4 & 1.69 & 13.7 \\
3-bottom disc plough & 20 & 0.9 & 1.55 & 0.43 \\
Mean & - & - & 0.07 & 2.82 \\
SE \pm & - & - & 3.30 & $*$ \\
C.V & - & - & $*$ & 11.00 \\
Level of significance & - & - & 1.62 & 9.67 \\
\hline Secondary tillage implement & & & 2.00 & 10.3 \\
\hline Modified chisel plough & 10 & 32 & 1.81 & 0.33 \\
3-bottom disc plough & 10 & 24 & 0.09 & 3.95 \\
Mean & - & - & 4.1 & NS \\
SE \pm & - & - & $*$ & \\
C.V & - & - & - & \\
Level of significance & - & & & \\
\hline
\end{tabular}

6.2 Theoretical and effective field capacity ( $h a \mathrm{hr}^{-1}$ )

Theoretical and effective field capacities were determined by applying of Equations (5) and (6). The modified chisel plough resulted in highly significant $(\mathrm{P}=0.01)$ higher theoretical and effective field capacity in comparison with the used of the 3-bottom disc plough (Table 2 and Fig.1 ). For the secondary operations, no significant differences were detected between the modified tandem disc harrow and the offset disc harrow (Table 2 and Fig. $1 \& 2$ ). These results indicated the superiority of the modified tillage implements over conventional ones, which was probably due to their greater width of cut.

Table 2: Theoretical and effective field capacities for one season $(2007 / 08)$

\begin{tabular}{lcc}
\hline \multicolumn{1}{c}{ Treatment } & $\begin{array}{c}\text { Theoretical field capacity } \\
\text { (ha hr-1) }\end{array}$ & $\begin{array}{c}\text { Effective field capacity } \\
\text { hr-1) }\end{array}$ \\
Primary tillage implement: & & \\
Modified chisel plough & 2.06 & 1.44 \\
3-bottom disc plough & 0.50 & 0.35 \\
Mean & 1.28 & 0.90 \\
SE \pm & 0.35 & 0.24 \\
C.V & 3.7 & 6.9 \\
Level of significance & $* *$ & $* *$ \\
Secondary tillage implement: & & \\
Modified tandem disc harrow & 1.86 & 1.30 \\
Offset disc harrow & 1.73 & 1.21 \\
Mean & 1.79 & 1.26 \\
SE \pm & 0.04 & 0.02 \\
C.V & 3.95 & 3.93 \\
Level of significance & $\mathrm{NS}$ & $\mathrm{NS}$ \\
\hline
\end{tabular}




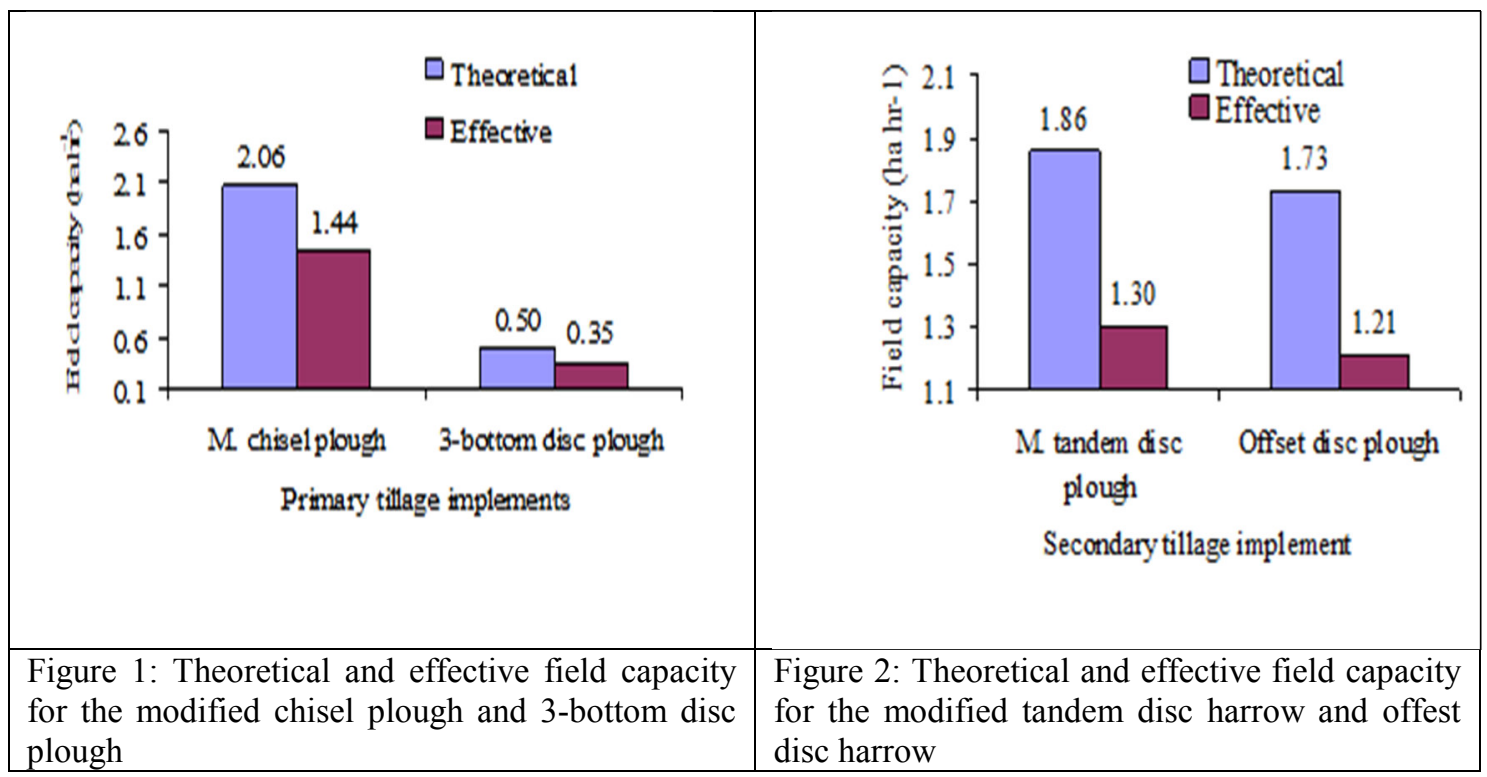

\subsection{Draught $(\mathrm{kN})$}

Table (3) represents the implement draught requirements for primary tillage implements. The modified chisel plough resulted in highly significant $(\mathrm{P}=0.01)$ higher draught in comparison with the 3 -bottom disc plough. For the secondary tillage implements the modified tandem disc harrow resulted in significantly $(\mathrm{P}=0.05)$ higher draught compared to the offset disc harrow (El-Awad and Crossley, 2003

Table 3: Effects of implement performance on the tractor drawbar power $(\mathrm{kW})$ for one season $(2007 / 08)$

\begin{tabular}{lcc}
\hline Treatment & Draught pull $(\mathrm{kN})$ & The required drawbar power $(\mathrm{kW})$ \\
\hline & Primary implement: & \\
\hline Modified chisel plough & 20.3 & 29.3 \\
Disc plough & 15.0 & 27.8 \\
Mean & 17.67 & 28.51 \\
SE \pm & 1.28 & 0.73 \\
C.V & 4.62 & 14.63 \\
Level of significance & $* *$ & NS \\
\hline \multicolumn{2}{l}{ Modified Tandem disc harrow } & 11.7 \\
Offset disc harrow & 9.2 & 21.1 \\
Mean & 11.17 & 18.3 \\
SE \pm & 0.51 & 19.73 \\
C.V & .14 .25 & 0.79 \\
Level of significance & $*$ & 14.63 \\
\hline
\end{tabular}

6.4 Drawbar power (KW) and Un-ploughed area (\%)

For both primary and secondary tillage operations no significant differences were detected for the tractor drawbar power. The results indicated that the value of drawbar used depends on forward speed (El-Awad and Crossley, 2003). Table (4) represents the un-ploughed areas within alley width, which was expressed in percent. In both season the modified chisel plough resulted in a highly significant $(\mathrm{P}=0.01)$ lower un-ploughed area within the alley in comparison with the use of the 3-botten disc plough. Therefore, the modified chisel plough resulted in an increase of the prepared land by $2 \mathrm{~m}$ width compared to the 3-bottom disc plough. These results indicated that the modified chisel plough resulted in a total cultivated width of $7.2 \mathrm{~m}$, while the 3-bottom disc plough resulted in about $5.2 \mathrm{~m}$ width for the alley cropping system of 8 -m width. 
Table 4: Effects of tillage system on the ploughed area of the alley cropping system for the two seasons (2007/08 and 2009/010)

\begin{tabular}{|c|c|c|c|c|c|c|}
\hline \multirow{2}{*}{ Tillage system } & \multicolumn{2}{|c|}{ Alley direction } & \multirow{2}{*}{ Mean } & \multirow{2}{*}{$\mathrm{SE} \pm$} & \multirow{2}{*}{ C.V } & \multirow{2}{*}{$\begin{array}{c}\text { Level of } \\
\text { significance }\end{array}$} \\
\hline & South & North & & & & \\
\hline \multicolumn{7}{|c|}{ 1st Season } \\
\hline $\begin{array}{l}\text { Modified system } \\
\text { Traditional system }\end{array}$ & $\begin{array}{l}5.0 \\
8.7\end{array}$ & $\begin{array}{c}3.7 \\
11.3\end{array}$ & 7.17 & 1.01 & 24.72 & $* *$ \\
\hline \multicolumn{7}{|c|}{ 2nd Season } \\
\hline $\begin{array}{l}\text { Modified system } \\
\text { Traditional system }\end{array}$ & $\begin{array}{c}6.0 \\
10.0\end{array}$ & $\begin{array}{c}4.0 \\
12.0\end{array}$ & 8.0 & 1.07 & 18.04 & $* *$ \\
\hline
\end{tabular}

\subsection{Pruned root length (cm) and Soil clod size distribution (\%)}

Table (5) displays the effect of the tillage systems on the pruning of tree lateral roots. In the first season the modified tillage system resulted in a very highly significant $(\mathrm{P}=0.01)$ higher destruction of root pruned length in comparison with the use of the traditional tillage system in the second season, but no significant differences were detected between tillage systems, which is probably due to the destruction of the tree superficial roots in the first season.

Table 5: Effect of the tillage system on lateral roots pruning for the two seasons (2007/08 and 2009/010).

\begin{tabular}{|c|c|c|c|c|c|c|}
\hline \multirow{2}{*}{ Tillage system } & \multicolumn{2}{|c|}{ Alley direction } & \multirow[b]{2}{*}{ Mean } & \multirow{2}{*}{$\mathrm{SE} \pm$} & \multirow{2}{*}{ C.V } & \multirow{2}{*}{ Level of significance } \\
\hline & South & North & & & & \\
\hline & & & & & & 1st Season \\
\hline $\begin{array}{l}\text { Modified system } \\
\text { Traditional system }\end{array}$ & $\begin{array}{l}180.4 \mathrm{~b} \\
189.7 \mathrm{~b}\end{array}$ & $\begin{array}{l}224.1 \mathrm{a} \\
191.2 \mathrm{a}\end{array}$ & 196.36 & 14.62 & 35.78 & $* * *$ \\
\hline \multicolumn{7}{|c|}{ 2nd Season } \\
\hline $\begin{array}{l}\text { Modified system } \\
\text { Traditional system }\end{array}$ & $\begin{array}{c}171.3 \mathrm{~b} \\
149.2\end{array}$ & $\begin{array}{l}192.2 \\
168.4\end{array}$ & 170.31 & 9.81 & 35.99 & NS \\
\hline
\end{tabular}

Table (6) shows the soil clod size distribution (\%) for the modified and traditional tillage systems, no significant differences were detected between tillage systems except at sieve opening of $<5>4 \mathrm{~cm}$, whereby the modified tillage system resulted in significantly $(\mathrm{P}=0.05)$ lower soil clod size distribution compared to the conventional ones. In the second season the modified tillage system resulted in significantly $(\mathrm{P}=0.05)$ lower clod size distribution with the sieve opening of 5 and $<3>2 \mathrm{~cm}$ in comparison with the traditional one. Generally the modified system resulted in a fine seedbed compared to the use of the traditional system.

Table 6: Effect of tillage systems on Infiltration rate for one season $(2007 / 08)$

\begin{tabular}{|c|c|c|c|c|}
\hline \multirow{3}{*}{ Time (min) } & \multicolumn{4}{|c|}{ Tillage system } \\
\hline & Modified & Traditional & Modified & Traditional \\
\hline & \multicolumn{2}{|c|}{ After ploughing operation } & \multicolumn{2}{|c|}{ After crop harvest } \\
\hline 5 & 27.7 & 14.1 & 13.5 & 8.0 \\
\hline 10 & 17.3 & $10 . .0$ & 9.0 & 6.6 \\
\hline 15 & 12.0 & 8.5 & 8.0 & 5.7 \\
\hline 20 & 10.3 & 7.2 & 7.1 & 5.6 \\
\hline 30 & 7.7 & 5.2 & 5.7 & 4.8 \\
\hline 45 & 6.0 & 4.2 & 4.8 & 3.7 \\
\hline 60 & 5.1 & 3.9 & 4.3 & 3.4 \\
\hline 90 & 4.9 & 3.1 & 3.5 & 2.6 \\
\hline 120 & 3.3 & 2.7 & 2.9 & 2.4 \\
\hline 180 & 2.5 & 1.9 & 2.5 & 1.9 \\
\hline 240 & 2.2 & 1.8 & 2.1 & 1.5 \\
\hline 300 & 1.9 & 1.6 & 1.9 & 1.3 \\
\hline Mean & \multicolumn{2}{|c|}{6.92} & \multicolumn{2}{|c|}{5.88} \\
\hline $\mathrm{SE} \pm$ & \multicolumn{2}{|c|}{0.81} & \multicolumn{2}{|c|}{0.31} \\
\hline C.V & \multicolumn{2}{|c|}{52.03} & \multicolumn{2}{|c|}{18.0} \\
\hline Level of significances & \multicolumn{2}{|c|}{$* * *$} & \multicolumn{2}{|c|}{$* * *$} \\
\hline
\end{tabular}

6.6 Infiltration rate (IR) $\left(\mathrm{cm} \mathrm{hr}^{-1}\right)$

Table (7) and Figs. (3 and 4) show the initial and final infiltration rate (IR) values for the two tillage systems. The initial and the final IR were determined twice. In both tests of the initial and final IR after crop harvest, the modified 
system resulted in very highly significant $(\mathrm{P}=0.01)$ higher infiltration rate than that obtained by the use of the 3 bottom disc plough. These results indicated that chiseling operation effectively breaks through the soil layer and enhances water percolation.

Table 7: Effect of tillage method on soil clod size distributions (\%) for the two seasons (2007/08 and 2009/010)

\begin{tabular}{|c|c|c|c|c|c|c|}
\hline Sieve opening $(\mathrm{cm})$ & $>5$ & $<5>4$ & $<4>3$ & $<3>2$ & $<2>1$ & $<1$ \\
\hline Tillage system & \multicolumn{6}{|c|}{ Clod size distribution $(\%)$} \\
\hline \multicolumn{7}{|c|}{ 1st season $(2007 / 08)$} \\
\hline Modified tillage system & 11 & $7 \mathrm{~b}$ & 7 & 12 & 16 & 41 \\
\hline Traditional tillage system & 20 & $12 \mathrm{a}$ & 11 & 13 & 17 & 38 \\
\hline Mean & 15.5 & 9.5 & 9 & 12.5 & 16.5 & 39.5 \\
\hline $\mathrm{SE} \pm$ & 2.3 & 1.5 & 1.3 & 0.7 & 0.8 & 2.3 \\
\hline C.V & 18.6 & 12.9 & 19.8 & 12.9 & 9.9 & 3.6 \\
\hline Level of significance & NS & $*$ & NS & NS & NS & NS \\
\hline \multicolumn{7}{|c|}{ 2nd season $(2009 / 010)$} \\
\hline Modified tillage system & $10 \mathrm{~b}$ & 11 & 11 & $12 \mathrm{~b}$ & 14 & 38 \\
\hline Traditional tillage system & $15 \mathrm{a}$ & 13 & 13 & $17 \mathrm{a}$ & 11 & 33 \\
\hline Mean & 12.5 & 12 & 12 & 14.5 & 12.3 & 35.2 \\
\hline $\mathrm{SE} \pm$ & 1.6 & 0.7 & 0.7 & 1.3 & 1.4 & 1.9 \\
\hline C.V & 5.7 & 9.0 & 9.0 & 7.4 & 28.3 & 12.2 \\
\hline Level of significance & $*$ & NS & NS & $*$ & NS & NS \\
\hline
\end{tabular}

$*=$ significant difference. $\mathrm{NS}=$ No significant difference

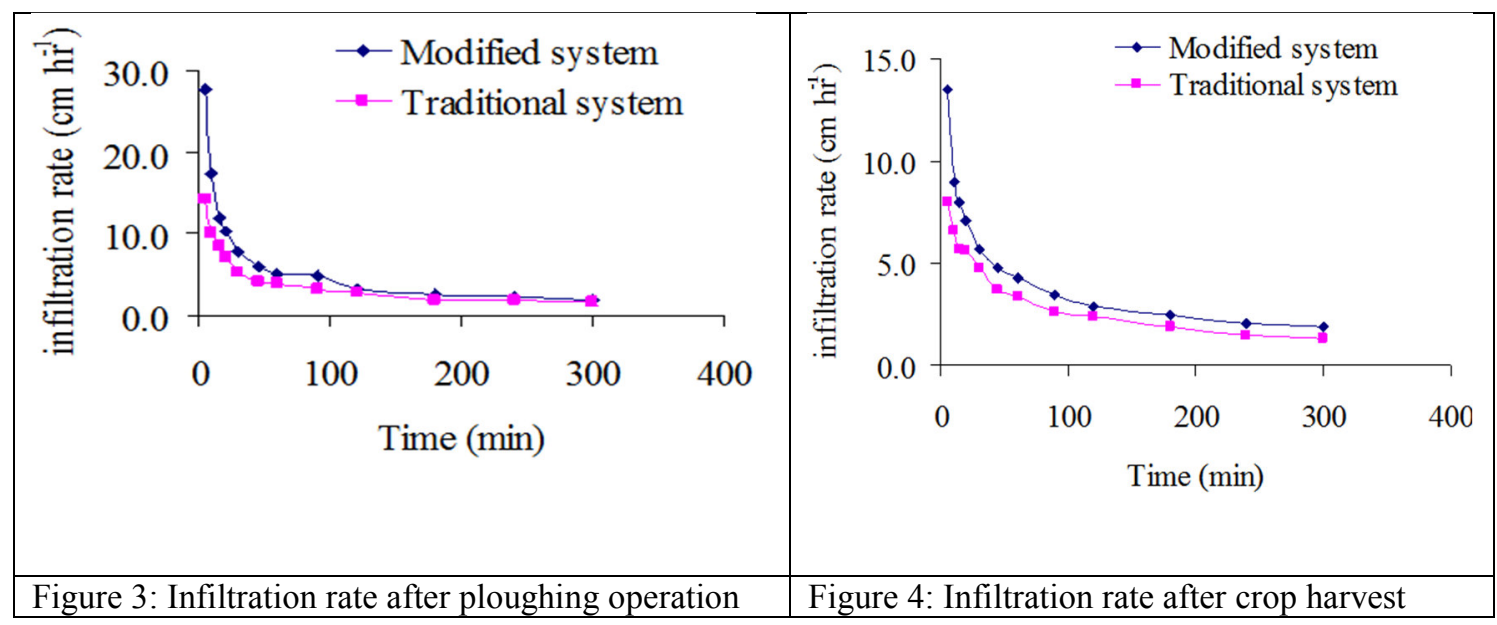

6.7 Soil bulk density and its corresponding moisture content

Table (8) presents the effects of tillage systems on soil bulk density and its corresponding soil moisture content at three stages of crop development (after crop emergence, at heading stage and at crop harvest) at three depths $0-10$, 10-20 and 20-30 cm. For each depth and stage of crop development, no significant difference were detected between tillage systems with respect to bulk density and its corresponding soil moisture content for the two seasons (2007/08 and 2009/010), except at crop emergence stage where the modified tillage system resulted in significantly $(\mathrm{P}=0.05)$ lower soil bulk density at all depths compared to the traditional one, but there were no significant differences with depth for each tillage system. This could be attributed to soil physical and chemical characters and to the low soil bulk density at the top of $20 \mathrm{~cm}$ depth (El-Waleed, 2000), and the direct effect of the type of tillage implements used. 
Table 8: Effects of tillage system on soil bulk density and corresponding moisture content

\begin{tabular}{|c|c|c|c|c|c|c|c|}
\hline \multirow{3}{*}{ Tillage system } & \multirow{3}{*}{$\operatorname{Depth}(\mathrm{cm})$} & \multicolumn{6}{|c|}{ Crop growth stage } \\
\hline & & \multicolumn{2}{|c|}{ Emergence } & \multicolumn{2}{|c|}{ Heading } & \multicolumn{2}{|c|}{ Harvest } \\
\hline & & SBD & SMC & SBD & SMC & SBD & SMC \\
\hline & \multicolumn{7}{|c|}{$1^{\text {st }}$ Season $(2007 / 2008)$} \\
\hline \multirow{3}{*}{ Modified tillage system } & $0-10$ & $1.05 \mathrm{~b}$ & 36.7 & 1.15 & 31.0 & 1.27 & 29.3 \\
\hline & $10-20$ & $1.08 \mathrm{~b}$ & 36.4 & 1.15 & 29.6 & 1.28 & 29.7 \\
\hline & $20-30$ & $1.06 \mathrm{~b}$ & 36.2 & 1.15 & 29.8 & 1.29 & 30.9 \\
\hline \multirow[t]{2}{*}{ Traditional tillage system } & $0-10$ & $1.11 \mathrm{a}$ & 34.3 & 1.20 & 28.5 & 1.31 & 29.1 \\
\hline & $10-20$ & $1.12 \mathrm{a}$ & 34.1 & 1.20 & 31.2 & 1.28 & 29.4 \\
\hline Means & $20-30$ & $1.11 \mathrm{a}$ & 34.8 & 1.21 & 30.8 & 1.27 & 29.9 \\
\hline C.V & & 1.09 & 35.5 & 1.18 & 30.2 & 1.28 & 29.9 \\
\hline $\mathrm{SE} \pm$ & & 4.0 & 8.2 & 3.7 & 11.7 & 4.3 & 7.2 \\
\hline \multirow[t]{4}{*}{ L. significant } & & 0.01 & 0.01 & 0.01 & 0.01 & 0.01 & 0.003 \\
\hline & & $*$ & NS & NS & NS & NS & NS \\
\hline & \multicolumn{7}{|c|}{$2^{\text {nd }}$ Season $(2009 / 010)$} \\
\hline & $0-10$ & $1.08 \mathrm{~b}$ & 30.1 & 1.15 & 36.6 & 1.28 & 29.7 \\
\hline \multirow[t]{2}{*}{ Modified tillage system } & $10-20$ & $1.04 \mathrm{~b}$ & 32.6 & 1.17 & 37.6 & 1.24 & 32.1 \\
\hline & $20-30$ & $1.11 \mathrm{a}$ & 29.0 & 1.16 & 37.7 & 1.30 & 29.2 \\
\hline \multirow[t]{2}{*}{ Traditional tillage system } & $0-10$ & $1.12 \mathrm{a}$ & 31.3 & 1.16 & 36.0 & 1.28 & 28.9 \\
\hline & $10-20$ & $1.11 \mathrm{a}$ & 30.9 & 1.16 & 35.3 & 1.27 & 30.8 \\
\hline Means & $20-30$ & 1.09 & 30.7 & 1.16 & 36.6 & 1.27 & 29.9 \\
\hline C.V & & 6.0 & 13.6 & 3.8 & 7.5 & 5.6 & 12.4 \\
\hline $\mathrm{SE} \pm$ & & 0.01 & 0.01 & 0.01 & 0.004 & 0.01 & 0.01 \\
\hline Level of significance & & $*$ & NS & NS & NS & NS & NS \\
\hline
\end{tabular}

6.8 Grain yield

Table (9) shows that the modified system resulted in significantly $(\mathrm{P}=0.05)$ higher yield compared to the traditional one, in the first season. In the second season, the modified system resulted in a highly significant $(\mathrm{P}=$ 0.01 ) increase in crop yield in comparison with the traditional system In comparison with the conventional tillage system, the increase of the two meters width with the modified tillage system resulted in an increase of $4 \%$ and $5 \%$ in the yield in the first and second season, respectively.

Table 9: Effects of tillage system on yield and yield component for the two seasons $(2007 / 08$ and 2009/010)

\begin{tabular}{lcc} 
Tillage System & \multicolumn{2}{c}{ Grain yield (ton/ha) } \\
\cline { 2 - 3 } & 1st season $(2007 / 08)$ & 2nd season $(2009 / 010)$ \\
\hline Modified system & $1.8 \mathrm{a}$ & $2.2 \mathrm{a}$ \\
Traditional system & $1.3 \mathrm{~b}$ & $1.2 \mathrm{~b}$ \\
Means & 1.5 & 1.7 \\
C.V & 28.0 & 41.4 \\
SE \pm & 0.5 & 0.9 \\
Level of significance & $*$ & $* *$ \\
\hline
\end{tabular}

\section{Conclusion}

The modified chisel plough has $4.4 \mathrm{~m}$ width of cut, while the 3-bottom disc plough has only $0.9 \mathrm{~m}$ with of cut. There were no significant differences between the modified chisel plough and the 3-bottom disc plough with regards to the required drawbar power. The modified system resulted in a highly significant $(\mathrm{P}=0.01)$ higher effective field capacity compared to the traditional system. The modified chisel plough resulted in a highly significant $(\mathrm{P}=0.01)$ lower un-ploughed area in comparison with the use of the 3-botten disc plough. Therefore, the modified chisel plough resulted in an increase of the prepared land by a $2 \mathrm{~m}$ width compared to the 3-bottom disc plough. The modified system resulted in a very a highly significant $(\mathrm{P}=0.001)$ higher number of the pruned roots length compared to the use of the disc plough. The modified tillage system resulted in a significantly $(0.05)$ lower soil clod size distribution $\%$, in comparison to the traditional one. The modified tillage system resulted in very a highly significant $(\mathrm{P}=0.001)$ initial and final deeper water percolation in comparison with the traditional tillage system. The modified chisel plough resulted in a significantly $(\mathrm{P}=0.05)$ higher grain yield compared to that obtained by the use 3-bottom disc plough. 


\section{References}

Ali, A. M. (1993). On the Use of Suitable Sample Plot Size and Tariff System for Efficient Inventory. Unpublished M.Sc. Thesis. University of Khartoum. Khartoum, Sudan.

Barger, E. L., Liljidah, J. B., Carclton, W, M. and E. G. Mckinbbin (1963).Traction theory. Tractor and their power units. 2nd edition. John Wiley and Sons. New York. Landon. Sydeny.

Blake, G. R. and H. K. Hartge. (1986). Bulk density. In. A kinte (Ed.) Mothed of soil analysis. Amer. Soc. Agron., Madison, Wisc. USA

Blake, G.R. Bulk density. In: BLACK, C.A. (1965) (Ed.) Methods of soil analysis: Part I. Madison: ASA. p.383390. Madison, USA.

Bukhari, S., J. M. Balloch, and A. N. Mirani. (1992). Comparative performance of disc harrowand Sat Harec. Agricltura Mechanization in Asia, Africa and Latin America (AMA). Japan. Vol.23 (3): 9-14.

El-Awad, S. E. A and C. P. Crossley. (2003). Feasibilty of High-Speed Cultivation Device. Agricultural Mechanization in Asia, Africa and Latin America (AMA). Japan. Vol-34. No.1.

Khalid, A. R. I. (2000). Importance of Soil Tillage for wheat Establishment and Yield in the Gezira Scheme. Unpublished M.S.c, thesis. Department of agri-engineering. Faculty of agricultural Sciences. University of Gezira. Wad Medani, Sudan.

Kang, B. T., Reynolds, L. and Atta-Krah, A.N. (1990) Alley farming. Advances in Agronomy 43, pp: 315-359. IITA, Ibadan, Nigeria

Kass, D.L., S.J.S. Araya., J.O. Sanchez., L.S. Pinto and P. Ferreira. (1992) Ten years experience with alley farming in central America. Paper represented at the International Alley Farming Conference, IITA, Ibadan, Nigeria, September 14-18, 1992.

Kepner, R. A., R. Bainer and E. L. Barger. (1978). Principles of Farm Machinery. 3rd edition. Pp:23-47. The Avi publishing company. Westport, CT,USA.

Landon, J. R. (1984). Booker tropical manual. A handbook for soil survey and agricultural land evaluation in the tropics and subtropics. Booker Agric. Longman Inc. 59-70. New York, USA.

Mckyes, E. (1985). Soil cutting and tillage Elsevier Sciences. Amsterdam - Oxford - New York. Tokyo.

Narain, P.,Singh, R.K.,Sindhwal, N.S., and Joshie,P., (1998). Water balance and water use efficiency of different land uses in western Himalayan valley region. Agricultural Water Management 37 (1998) 225 - 240. 8) Ong, C.k., Corlet,J.E., Singh, R.P and Black. C.K. 1991. Above- and below-ground interactions in agroforestry. Forest Ecology and Management. 45: 45 - 57.

NFC (National Forests Corporation). (1994). Studies on Consumption of Forest Products in the Sudan (1993). Preliminary Results Findings, Summary Tables. Forests National Corporation, Khartoum. Sudan.

Shapo, A. E. and A. H. Adam. (2006). Effects of Alley-cropping Systems on Crop Productivity and Water Use Efficiency in Semi-desert Region of Northern Sudan Prosperity and Poverty in a Globalised World Challenges for Agricultural Research. Tropentag. Bonn, Germany.

Shapo, H. E. and H. S. Adam (2008). Modification of Microclimate and Associated Food Crops Productivity in Alley-cropping system in Northern Sudan, In Shibu Jose and Andrew Gordon (eds.). Toward Agroforestry Design: an Ecological Approach Springer, Advances in Agroforestry Series, Volume 4, pp 97-109.

Shapo, H. E. and H. S. Adam. (2003). Water-use in Alley-Cropping Microclimate, Proceedings of the Conference on Water Harvesting and Future of Development in Sudan, August 2003, Khartoum, Sudan, pp $35-47$.

Yu, S. Wang S.; Wei P.; Zhu Z.; Lu X. Y.; and Fang Y. (1997). A study on Paulownia - Tea Intercropping SystemMicroclimate Modification and Economic Benefits. Copyright 1997 (C) International Development Research Centre, Ottawa, Canada reference@idrc.ca|Updated: 10 November 1998. 